\title{
Extending the Vase Life of Gerbera (Gerbera hybrida) Cut Flowers Using Chemical Preservative Solutions
}

\author{
W.A.N.T. De Silva ${ }^{*}$ J.P. Kirthisinghe ${ }^{1}$ and L.M.H.R. Alwis ${ }^{2}$ \\ Postgraduate Institute of Agriculture \\ University of Peradeniya \\ Sri Lanka
}

\begin{abstract}
The experiment was conducted to find out a chemical preservative solution to extend the vase life and reduce the stem bending of gerbera (Gerbera hybrida). Calcium chloride $\left(\mathrm{CaCl}_{2} ; 1 \%\right)$, lime juice (0.5\%), vinegar (0.6\%) and sucrose (2\%) were used in the eight treatments, arranged in a Complete Randomized Design with 10 replicates. The vase life and stem bending percentage were observed daily. Fresh weight of flower heads and stems were measured. Flower quality was recorded after 12 days by a scale developed for the said purpose. Qualitative data were analyzed by Kruskal-Wallis test and quantitative data were analyzed by using one way ANOVA. Significant differences $(p<0.05)$ were observed in the fresh weight of flower heads and stems. The highest fresh weight of flower heads $(7.3 \mathrm{~g})$, fresh weight of stems $(4.2 \mathrm{~g})$, zero stem bending percentage and the maximum vase life (16 day) were obtained in the treatment containing sucrose $2 \%+$ vinegar $0.6 \%+$ $\mathrm{CaCl}_{2} 1 \%$ in distilled water.
\end{abstract}

Keywords: $\mathrm{CaCl}_{2}$, lime, stem bending, vinegar

\section{INTRODUCTION}

Gerbera (Gerbera hybrida) belongs to the family Asteraceae. They are attractive flowers and are available in a wide range of colours such as yellow, orange, pink, crimson, red, purple and white. Gerbera var. "Queen Leen" is widely used as a cut flower for vase decoration and other floral arrangements. Cut flowers with long vase-life, fetches high market prices.

Keeping quality is an important parameter for evaluation of cut flowers for both domestic and export markets. Stem (stalk) bending is one of the major problems in gerbera cut flowers, and addition of chemical preservatives to the vase solution increases the vase-life of cut flowers (Dissanayake et al., 2009). The vase life of gerbera could be extended by using chemicals such as silver nitrate $\left(\mathrm{AgNO}_{3}\right)$ and 8-Hydroxyquinoline citrate (8-HQC), which are expensive and hazardous to the environment (Ekanayake et al., 2008) and thus, growers could not use these postharvest treatments.

Department of Crop Science, Faculty of Agriculture, University of Peradeniya, Sri Lanka

Faculty of Animal Science and Export Agriculture, Uva Wellassa University, Sri Lanka

Corresponding author: n_nilukshi@yahoo.com 
Dissanayake et al. (2009) found that Clorox, lime juice and vinegar are inexpensive and less hazardous and could be used as a remedy to extend the vase life of lotus flower. The $\mathrm{CaCl}_{2}$ and $\mathrm{Al}_{2}\left(\mathrm{SO}_{4}\right)_{3}$ can strengthen the stem and can limit the stem bending percentage (Ekanayake et al., 2008). Therefore, the present study was conducted to identify a method to extend the vase life of gerbera (G. hybrida).

\section{MATERIALS AND METHODS}

The experiment was conducted at the Biology Laboratory of the Uva Wellassa University, Sri Lanka from January 2012 to May 2012, which included preliminary studies carried out from January to March 2012 to select the appropriate chemical concentrations for the present experiment. Flowers were harvested in April 2012 when the outer ray florets were completely elongated and two rows of disc florets were completely developed. The flowers were collected around $6.00 \mathrm{am}$, immediately placed in water, and transported to the experimental location without any delay. Flowers in the same size (about $9.0 \mathrm{~g}$ and $7.5 \mathrm{~cm}$ diameter) were selected for the experiment and the stems were re-cut leaving about $30 \mathrm{~cm}$ from the flower head prior to placing them in the treatment solutions (Table 1). Glass test tubes $(12.5 \mathrm{ml})$ were used for the experiment. The treatment solutions were prepared freshly and dispensed into the test tubes, and flowers with $30 \mathrm{~cm}$ stems were subsequently placed in the solutions. The solutions were renewed once in three days. Flowers were kept in an air conditioned room at $20{ }^{\circ} \mathrm{C}$ with a continuous uniform light intensity of two fluorescent bulbs (cool white), each of 40 watts for $12 \mathrm{hrs}$ per day.

Table 1. Treatment solutions used in the experiment

\begin{tabular}{cl}
\hline Treatment & \multicolumn{1}{c}{ Solution } \\
\hline T1 & Tap water \\
T2 & Distilled water \\
T3 & Vinegar 0.6\% with distilled water \\
T4 & Lime juice 0.5\% with distilled water \\
T5 & Sucrose 2\% + Vinegar 0.6\% with distilled water \\
T6 & Sucrose 2\% + Lime juice $0.5 \%$ with distilled water \\
T7 & Sucrose 2\% + Vinegar 0.6\% $\mathrm{CaCl}_{2} 1 \%$ with distilled water \\
T8 & Sucrose 2\% + Lime juice $0.5 \%+\mathrm{CaCl}_{2} 1 \%$ with distilled water \\
\hline
\end{tabular}

The experiment with eight treatments was conducted in completely randomized design (CRD) with 10 replicates. Vase life and stem bending percentage were recorded daily. Fresh weight of flower heads and fresh weight of stems were measured after 12 days. The overall appearance and the quality of flowers were recorded after 12 days by using a scale developed for the evaluation of flower quality (Fig. 1). The vase life of flowers was measured as the numbers of days taken to reach the scale 4 in Fig. 1. 


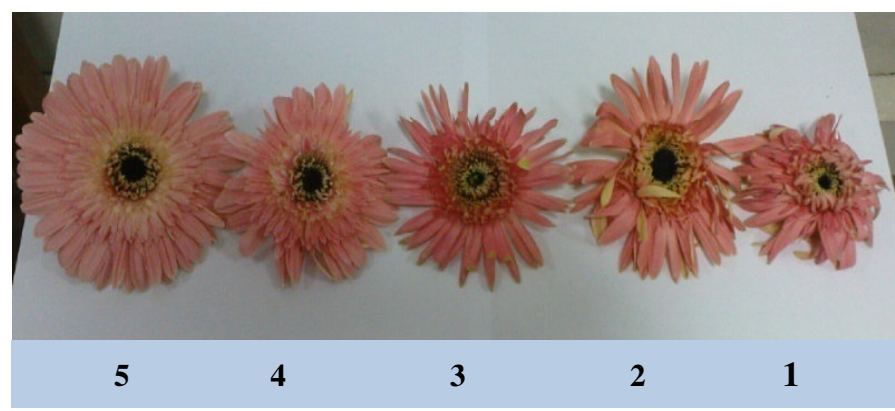

Fig. 1. Scale used for the evaluation of flower quality
Scores:

5 - Full bloom with no petal discoloration and wilting

4 - Full bloom with no petal discoloration and slight wilting

3 - Slight petal discoloration with moderate wilting

2 - High level of petal discoloration with moderate wilting

1 - Wilted flower with discoloured petals

The qualitative data were analyzed by Kruskal-Wallis test. Quantitative data were analyzed using one way ANOVA by the MINITAB computer software package. The mean values were compared by Tukey's test at $\mathrm{p}=0.05$.

\section{RESULTS AND DISCUSSION}

There was a significant effect $(\mathrm{p}<0.05)$ of treatments on the fresh weight of flower heads and fresh weight of stems (Table 2). The fresh weight of flower heads and the fresh weight of stems were significantly different between $\mathrm{T} 2$ and $\mathrm{T} 7$. The highest fresh weight of flower heads $(7.4 \mathrm{~g})$ and stems $(4.3 \mathrm{~g})$ were observed in $\mathrm{T} 7$ with sucrose $2 \%+$ vinegar $0.6 \%+$ $\mathrm{CaCl}_{2} 1 \%$ with distilled water. The lowest fresh weight of flower heads (4.6 g) and stems (2.1 g) were observed in $\mathrm{T} 2$ with distilled water only.

Table 2. Fresh weight of flower heads and stems, vase life and stem bending percentage in different treatments

\begin{tabular}{ccccc}
\hline Treatment & $\begin{array}{c}\text { Fresh weight of } \\
\text { flower heads }(\mathbf{g})\end{array}$ & $\begin{array}{c}\text { Fresh weight of } \\
\text { stems }(\mathbf{g})\end{array}$ & $\begin{array}{c}\text { Vase life } \\
\text { (Days) }\end{array}$ & $\begin{array}{c}\text { Stem bending } \\
\text { \% after 12 days }\end{array}$ \\
\hline T1 & $5.71^{\mathrm{ab}}$ & $3.00^{\mathrm{ab}}$ & $11.33^{\mathrm{bc}}$ & 60 \\
T2 & $4.62^{\mathrm{b}}$ & $2.07^{\mathrm{b}}$ & $10.67^{\mathrm{c}}$ & 80 \\
T3 & $5.94^{\mathrm{ab}}$ & $3.07^{\mathrm{ab}}$ & $12.67^{\mathrm{b}}$ & 40 \\
T4 & $5.83^{\mathrm{ab}}$ & $3.68^{\mathrm{ab}}$ & $12.67^{\mathrm{b}}$ & 50 \\
T5 & $6.64^{\mathrm{ab}}$ & $3.66^{\mathrm{ab}}$ & $14.33^{\mathrm{a}}$ & 40 \\
T6 & $6.63^{\mathrm{ab}}$ & $3.51^{\mathrm{ab}}$ & $14.67^{\mathrm{a}}$ & 40 \\
T7 & $7.38^{\mathrm{a}}$ & $4.28^{\mathrm{a}}$ & $16.67^{\mathrm{a}}$ & 0 \\
T8 & $6.48^{\mathrm{ab}}$ & $4.22^{\mathrm{a}}$ & $14.66^{\mathrm{a}}$ & 20 \\
\hline p value & 0.01 & 0.02 & 0.00 & \\
SD & 0.46 & 0.29 & 0.57 & \\
\hline
\end{tabular}

Within a column, means followed by the same letter are not significantly different at $\mathrm{P}=0.05$

A significant difference $(\mathrm{p}<0.05)$ was observed among the different chemical solutions on the quality of flowers. Treatments with average rank are shown in Fig. 2. The highest 
average rank was observed in $\mathrm{T} 7$ and it was considered as the best among the tested treatments.

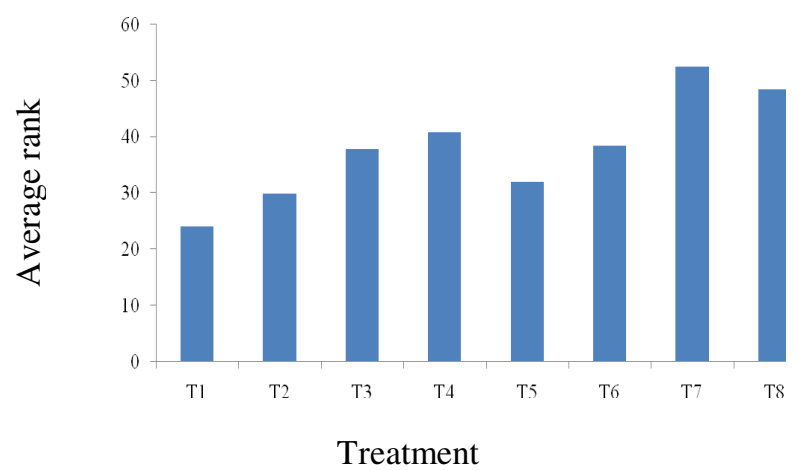

\section{Fig. 2. The average rank for the appearance (quality) of flowers 12 days after harvest}

The highest stem bending percentage and the lowest vase life were observed in the treatment $\mathrm{T} 2$, with distilled water only. Zero stem bending percentage and the maximum vase life were observed in treatment $\mathrm{T} 7$ that consisted of sucrose $2 \%+$ vinegar $0.6 \%+\mathrm{CaCl}_{2} 1 \%$ with distilled water.

A negative relationship between the fresh weight of flower heads and stem bending percentage was observed during the experiment $(r=-0.924)$, and also negative relationship between the fresh weight of flower stems and stem bending percentage was observed $(r=-$ 0.906). According to Meeteren (1978), the fresh weight of stems increased with uptake of water, which helps maintain the turgidity of stem and reduce stem bending percentage. Vase solutions with an acidifier (T3, T4, T5, T6, T7 and T8) resulted in a comparatively higher fresh weight and lower stem bending than T1 (tap water) and T2 (distilled water) only. Byczynski (1997) reported that vinegar and lime act as acidifiers and bactericides, which may reduce the $\mathrm{pH}$ of solutions and increases water uptake.

Treatments with sucrose (T5, T6, T7 and T8) showed a long vase life and a lower stem bending percentage. Sucrose is widely used as a floral preservative in many countries. Steinitz (1982) reported that sucrose act as a food source and a respiratory substrate, which helps delay the degradation of proteins and improves the water balance of cut flowers. Halevy and Mayak (1979) found that the addition of sucrose to the solution increased the mechanical rigidity of the stem by inducing cell wall thickening and lignification of vascular tissues. Sucrose antagonizes the effect of ABA, which promotes senescence. Sugars usually tend to promote microbial growth as observed in the present experiment, and hence the chemical solutions were replaced once in three days. The combination of sugars and biocides may have resulted in an extended vase-life of cut flowers.

The lowest stem bending percentages were obtained in T7 and T8 treatments, which consisted of $\mathrm{CaCl}_{2}(1 \%)$ in addition to the acidifier and sucrose. Salisbury and Ross (1986) reported that $\mathrm{Ca}$ helps to strengthen plant cell wall structure, while Jones (2001) reported that chlorine is an important biocide that prevents contaminations by microorganisms when the solution is rich in food. Ekanayake et al. (2008) found that the stem bending was one of the problems in gerbera cut flowers and lower concentrations $(1 \%)$ of $\mathrm{CaCl}_{2}$ were effective in preventing stem bending in gerbera. 
The fresh weight of flower head, the fresh weight of stem and vase life were higher in the treatment $\mathrm{T} 1$ (tap water) than the treatment T2 (distilled water), and stem bending percentage was lower in the treatment T2 (distilled water) than the treatment T1 (tap water). That result may be due to, consisting of Chlorine in tap water and distilled water dose not consist with chlorine.

\section{CONCLUSIONS}

The maximum vase life of 16 days with zero stem bending percentage and high quality of flowers were resulted in the vase solution containing sucrose $2 \%+$ vinegar $0.6 \%+\mathrm{CaCl}_{2} 1 \%$ in distilled water (T7). Ten days of vase life and poor quality flowers were observed in flowers treated with distilled water only (T2).

\section{REFERENCES}

Byczynski, L. (1997). The flower farmer, an organic grower's guide to raising and selling cut flowers, Vermont. Chelsa Green Publishing Company, pp. 99-105.

Dissanayake G.K.G.S.D., Senevirathna, C.N., Kirthisinghe, J.P. and Krishnarajah, S.A. (2009). Study on extending vase life of Lotus using different vase solutions. Proceedings of the National Symposium on Floriculture Research, pp 30-38.

Ekanayake, S.C., Senevirathna, K.A.C. and Peris, S.E. (2008). Effect of coconut water and Chloride on extending vase life of cut Gerbera. Proceedings of the National Symposium on Floriculture Research, pp. 41-47.

Halevy, A.H. and Mayak, S. 1979. Senescence and post-harvest physiology of cut flowers: Part 1. Horticultural Reviews 1, 204-236

Jones, R. (2001). Caring for cut flowers, $2^{\text {nd }}$ Ed. Lanklinks Press, CSIRO Publishing.

Meeteren van U. (1978). Water relations and keeping-quality of cut gerbera flowers. The cause of stem break. Scientia Hortic. 8, 65-74.

Salisbury, F.B. and Ross, C.W. 1996. Plant physiology. Wadworth, California, pp. 247-277.

Steinitz, B. (1982). Role of sucrose in stabilization of cut gerbera flower stalks. Gartenbouwissenschaft 47(2), 77-81. 